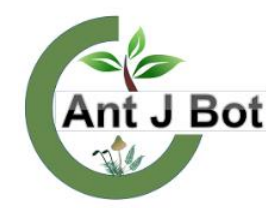

\title{
Cell growth inhibitory potential of Craterellus cornucopioides (L.) Pers. together with antioxidant and antimicrobial properties
}

\author{
Sevim KOL, Aykut BOSTANCI, Aytaç KOCABAŞ, Yasin UZUN, Gökhan SADİ* \\ Karamanoğlu Mehmetbey University, K.Ö. Science Faculty, Department of Biology, Karaman, Turkey \\ *sadi.gokhan@gmail.com
}

Received : 09.04.2018

Accepted : 07.05.2018

\section{Antioksidan ve antimiktobiyal özellikleri ile birlikte Craterellus cornucopioides $(L$.$) Pers. türünün hücre büyümesi baskılama potansiyeli$}

\begin{abstract}
Craterellus cornucopioides (L.) Pers which is also known as trumpet of death or horn of plenty, is a wild edible macrofungus. This study was conducted to elucidate the potential health beneficial properties of $C$. cornucopioides. Bioactive ingredients (phenolics, flavonoids, $\beta$-carotene and lycopene) and DPPH radical scavenging activities were determined. Additionally, cell growth inhibitory effects on HepG2 cells together with some bacteria were evaluated. Accordingly, water and methanol extracts contains $37.71 \pm 1.42 \mu \mathrm{g} / \mathrm{mg}$ and $13.78 \pm 1.60 \mu \mathrm{g} / \mathrm{mg}$ phenolic contents, respectively. Similarly, methanolic extracts have higher $\beta$-caroten and lycopene content as compared to aqueous extracts. In parallel with these antioxidants, methanolic extracts have also higher DPPH scavenging activity $\left(\mathrm{IC}_{50}: 5.26 \pm 0.67 \mathrm{mg} / \mathrm{ml}\right.$ ). Besides, water extracts have higher flavonoid contents $(2.13 \pm 0.06 \mu \mathrm{g} / \mathrm{mg})$ then the methanolic extracts. C. cornucopioides has also an important cell growth inhibitory effects on HepG2 cell ( IC $_{50}: 18.41 \pm 1.10 \mathrm{mg} / \mathrm{ml}$ for aqueous extracts and $\mathrm{IC}_{50}: 3.14 \pm 1.07 \mathrm{mg} / \mathrm{ml}$ for methanolic extracts). Moreover, both extracts were effective on six different bacteria tested. As a result, this study indicates that $C$. cornucopioides could reduce the cellular oxidative stress because of its high antioxidant ingredients, inhibit the growth of pathogen microrganisms and have some degree of cell growth inhibitory potential at least to the HepG2 cells.
\end{abstract}

Key words: Craterellus cornucopioides, antioxidant, antibacterial, cytotoxicity, HepG2

Özet: Ölüm trompeti veya bolluk boynuzu olarak da bilinen Craterellus cornucopioides (L.) Pers, yenilebilir bir makrofungustur. Bu çalışma Craterellus cornucopioides (L.) Pers mantarının sağlık açısından yararlı özelliklerini açığa çıkarmak amacıyla yapılmıștır. Calıșmada ilgili mantarın biyoaktif içerikleri (fenolikler, flavonoidler, $\beta$-karoten ve likopen) ve DPPH radikal süpürücü aktiviteleri belirlenmiştir. Ek olarak, HepG2 hücreleri ve bazı bakteri türleri üzrine hücre büyümesini baskılayıcı etkileri değerlendirilmiştir. Buna göre, su ve metanol ekstraktları sırasıyla $37.71 \pm 1.42 \mu \mathrm{g} / \mathrm{mg}$ ve $13.78 \pm 1.60 \mu \mathrm{g} / \mathrm{mg}$ fenolik içeriğe sahiptir. Benzer şekilde, metanol ekstraktları sulu ekstrelere kıyasla daha yüksek $\beta$-karoten ve likopen içeriğine sahiptir. Bu antioksidanlara paralel olarak, metanol ekstraktları da DPPH süpürme aktivitesine daha fazla sahiptir (ICso: $5.26 \pm 0.67 \mathrm{mg} / \mathrm{ml})$. Ayrıca su ekstraktları, metanol ekstraklarına göre daha yüksek flavonoid içeriğine $(2.13 \pm 0.06 \mu \mathrm{g} / \mathrm{mg})$ sahiptir. C. cornucopioides, HepG2 hücresi üzerinde de önemli bir hücre büyümesi engelleyici etkiye sahiptir (IC S0 $_{50}$ su ekstratları için $18.41 \pm 1.10 \mathrm{mg} / \mathrm{ml}$ ve metanol ektraktları için $\mathrm{IC}_{50}: 3.14 \pm 1.07 \mathrm{mg} / \mathrm{ml}$ ). Buna ek olarak, her iki ekstrakt da test edilen altı farklı bakteri türü üzeine etkili olmuştur. Sonuç olarak, bu çalışma C. cornucopioides'in yüksek antioksidan bileşenleri nedeniyle hücresel oksidatif stresi azaltabildiğini, patojen mikroorganizmalarının büyümesini inhibe edebileceğini ve en azından HepG2 hücrelerine bir miktar hücre büyümesi inhibitör potansiyeline sahip olduğunu göstermektedir.

Anahtar Kelimeler: Craterellus cornucopioides, antioksidan, antibakteriyel, sitotoksisite, HepG2

\section{Introduction}

Fungi are eukaryotic and heterotrofic organisms that are composed of tubular filamentous cells, free chlorophyll and create spores. They could not produce their own foods thus which live as saprophyts, mycorrhizal and parasite. Edible mushrooms contain macro-molecules, which are normally 19 to $35 \%$ protein, and all protein content almost comprises essential amino-acids. They also include polyunsaturated fatty acids $(72-85 \%)$ and carbohydrates (51-88\%) according to dry or fresh weight (Chang et al., 1996). Medicinal mushrooms have important therapeutic features and, due to these features, they have been used against many kinds of disease for treatment in traditional medicine. For example, many genre mushroom such as Agaricus, Aleurodiscus, Clitocybe, Coprinus, Daedalea, Ganoderma, Lentinula, Merulius, Pleurotus, Polyporus, Poria, Psathyrella and Tricholoma rise in value due to their major properties such as anti-microbial (Chang et al., 2012), anti-viral (Pan et al. 2013), anti-oxidant (Palacios et al., 2011), anti-cancer (Mattila et al., 2000).

Free radicals have been generated by many biological pathways or infections in organisms, damaging the cellular components such as organelles (Y1ld1z et al., 2015, Manivannan et al., 2011) and they are quenched by antioxidant molecules or related antioxidant enzymes. Mushrooms gain importance according to rich bioactive compounds such as polyphenols, polysaccharides, vitamins, carotenoids and minerals (Kozarski et al. 2015, Cheung et al., 2002). Studies have shown that antioxidant rich foods might play an important role in reducing the risk of disease, such as cardiovascular diseases, stroke and cancer (Gan et al., 2013, Barros et al., 2007; Jagadish et al. 2009). Therefore, antioxidants in edible mushrooms might act against reactive oxygen species and contribute to create antioxidant responses. Macrofungi also gain importance in cancer inhibition and treatment with the secondary metabolites found in their structure. Moreover, they also could be used against microbial infections. Some metabolites might prevent the growth of certain bacterial and fungal pathogens (Alves et al., 2012).

For example, applanoxidic acid A isolated from Ganoderma annulare (Fr.) Gilbn. has been showed to be effective against Trichophyton mentagrophytes. Moreover, 5a-ergosta- 7,22-dien-3b-ol 5,8-epidioxy-5a,8a-ergosta- 
6,22-dien-3b-ol isolated from Ganoderma applanatum (Pers.) Pat., have been shown to affect several grampositive and gram-negative microorganisms (Smania et al., 1999, Smania et al., 2003). In this study, $C$. cornucopioides was investigated for its antimicrobial, antioxidant, and cytotoxic properties to contribute the studies that are done in pharmaceutical area.

\section{Materials and Method}

\subsection{Preparation of Fungal Extracts}

Craterellus cornucopioides (L.) Pers that was used in this study was collected from Trabzon province with a voucher number of Yuzun 1852. The samples are kept at Karamanoglu Mehmetbey University, Kamil Özdağ Science Faculty, Department of Biology. Water and methanol extracts were prepared to examine cytotoxic, antioxidant and antimicrobial effects. Ten grams of entire mushrooms were homogenized by using liquid nitrogen, mortar and pestle and exposed to extraction in $300 \mathrm{ml}$ methanol or distilled water with Soxhlet extraction apparatus. Then, extracts were concentrated in a rotary evaporator, lyophilized and stored at $+4^{\circ} \mathrm{C}$ for further use.

\subsection{Determination of Total Phenolic Content}

Folin-Ciocalteu method was used for the determination of total phenolic content (Taga et al., 1984). Gallic acid (0.02 to $1.00 \mathrm{mM})$ was used as standard. Fungal extracts (10 $\mathrm{mg} / \mathrm{ml})$ and standards $(0.02-1.00 \mathrm{mM})$ were placed in 20 $\mu 1$ microplate wells. Afterwards, $20 \mu \mathrm{l}$ of Folin reagent $(2 \mathrm{~N})$ was added and mixed by pipetting. After incubation for $3 \mathrm{~min}$ in the dark, $20 \mu \mathrm{l}$ of $35 \%(\mathrm{w} / \mathrm{v})$ sodium carbonate and $140 \mu \mathrm{l}$ of $\mathrm{dH}_{2} \mathrm{O}$ were added to the plate and incubated for $10 \mathrm{~min}$ in the dark. The absorbance values were recorded against the blank tube at $725 \mathrm{~nm}$ and the amount of total phenolic content in one mg extract was calculated using a standard calibration curve generated with gallic acid.

\subsection{Determination of Total Flavonoid Content}

Total flavonoids of water and methanol extracts were determined according to method (Pal et al., 2010) with slight modifications. A volume of $50 \mu \mathrm{l}$ of extracts $(10$ $\mathrm{mg} / \mathrm{ml})$ were mixed with $215 \mu \mathrm{l}$ of ethyl alcohol $(80 \%$ $\mathrm{v} / \mathrm{v}), 5 \mu \mathrm{l}$ of aluminum nitrate $(10 \% \mathrm{w} / \mathrm{v})$ and $5 \mu \mathrm{l}$ potassium acetate $(1 \mathrm{M})$ in microtiter plates and incubated for $40 \mathrm{~min}$ at room temperature. After reading at $415 \mathrm{~nm}$, total flavonoid contents were calculated according to following equation:

Total flavonoid contents $(\mu \mathrm{g} / \mathrm{mg}$ extract $)=\left(\mathrm{A}_{415}+\right.$ 0.01089)/0.002108

\subsection{Determination of $\beta$-carotene and Lycopene Contents}

Different extracts with water and methanol that were obtained from $C$. cornucopioides were reextracted with 10 $\mathrm{ml}$ of acetone:hexane (4:6) mixture and filtered through Whatman No. 4 filter paper to determine $\beta$-carotene and lycopene contents. After filtration, absorbance of the filtrates was measured at 453, 505 and $663 \mathrm{~nm}$. $\beta$-carotene and lycopene contents were calculated according to following equations. $\beta$-carotene content $(\mathrm{mg} / 100 \mathrm{mg})=0.216 \mathrm{~A}_{663}-0.304 \mathrm{~A}_{505}$ $+0.452 \mathrm{~A}_{453}$

Lycopene content $(\mathrm{mg} / 100 \mathrm{mg})=-0.0458 \mathrm{~A}_{663}+0.372$ $\mathrm{A}_{505}-0.0806 \mathrm{~A}_{453}$

\subsection{Identification and Quantification of Main} Phenolic Compounds by HPLC

Phenolic substance identification was carried out with HPLC (Shimadzu LC-20AD system, Japan). Data was processed using LC Solution software (Shimadzu, Japan). As mobile phase; (A) $0.1 \%$ (v/v) formic acid and (B) acetonitrile mixtures were used as gradient. Gradient elution conditions are as follows: Starting $20 \%$ B; $0-10$ $\min 20 \%-30 \% \mathrm{~B} ; 10-40 \min 30-40 \% \mathrm{~B} ; 40-60 \min 40 \%-$ $560 \% \mathrm{~B} ; 60-80 \mathrm{~min} 60-80 \% \mathrm{~B}$; and finally, $90 \mathrm{~min}$ from $80 \%-20 \% \mathrm{~B}$. The flow rate was set to $1 \mathrm{ml} / \mathrm{min}$, the column temperature was fixed at $30^{\circ} \mathrm{C}$. Phenolic compounds were identified by using standards that were in known concentration. Gallic acid, catechin, epicatechin, epigallocatechin gallate, syringic acid, p-coumaric acid, rosmarinic acid, t-resveratrol and quercetin standard curves were constructed and the amount of these phenolics in C. cornucopioides extracts were quantitatively determined. At least three applications were performed for each sample (Standard or sample) and sample absorbances were monitored at $271 \mathrm{~nm}, 280 \mathrm{~nm}$ and $309 \mathrm{~nm}$.

\subsection{Determination of Reducing Power}

After the slight modifications that were made to adopt the method to microplate measurement, reducing powers of different extracts were determined according to the previously prescribed protocol (Sadi et al., 2015). Gallic acid $(0.01-0.10 \mathrm{mM})$ was used as a standard antioxidant. Briefly, in a total volume of $200 \mu \mathrm{l}$, various concentrations of $50 \mu 1$ mushroom extracts $(2,4,6,8,10 \mathrm{mg} / \mathrm{ml})$ were mixed with $75 \mu \mathrm{l}$ phosphate buffer $(0.2 \mathrm{M} \mathrm{pH}: 6.6), 75 \mu \mathrm{l}$ potassium ferricyanide $(1 \% \mathrm{w} / \mathrm{v})$ and incubated at $50^{\circ} \mathrm{C}$ for $20 \mathrm{~min}$. After adding $75 \mu \mathrm{l}$ trichloroacetic acid $(10 \%$ $\mathrm{w} / \mathrm{v})$, samples were centrifuged for $10 \mathrm{~min}$ at $1000 \mathrm{~g}$ and supernatants $(75 \mu \mathrm{l})$ were transferred to another microtiter plate. Then, they were mixed with $75 \mu$ l distilled water and $15 \mu \mathrm{l}$ iron (III) chloride $(0.1 \% \quad \mathrm{w} / \mathrm{v})$. Spectrophotometric measurements were employed at 700 $\mathrm{nm}$ and the effective concentrations $\left(\mathrm{EC}_{50}\right)$ at which the absorbance was 0.500 for the reducing power was calculated.

\subsection{Determination of DPPH Radical Scavenging Activity}

DPPH (2,2-diphenyl-1-picrylhydrazyl) radical scavenging activity of $C$. cornucopioides was measured (Türkoglu et al., 2007) to determine antioxidant power. Accordingly, different concentration $C$. cornucopioides extracts $(0.25$ to $10 \mathrm{mg} / \mathrm{ml})$ and gallic acid (0.005 to $0.2 \mathrm{mM})$ were prepared for measuring the elimination activity of DPPH radical. From C. cornucopioides extracts and standards, 20 $\mu \mathrm{l}$ was added to each microplate well and $180 \mu \mathrm{DPPH}$ (0.06 mM in methanol) was added. After incubation for 60 min in dark, the reduction of DPPH radical was followed by the absorbance values that were measured at $517 \mathrm{~nm}$. Free radical capturing activities were calculated according to the following formula. The DPPH radical scavenging activity (RSA) was calculated as $\mathrm{IC}_{50}$ values for each sample. 


$$
\text { RSA }(\%)=\frac{\text { DPPH absorbance }- \text { DPPH and extract absorbance }}{\text { DPPH absorbance }}
$$

\subsection{Determination of cell growth inhibitory potential}

\subsubsection{Antimicrobial properties}

Six test bacteria; Bacillus subtilis, Enterococcus faecalis, Bacillus licheniformis, Staphylococcus aureus (ATCC 2921) as Gram Positive; Agrobacterium tumefaciens and Escherichia coli (0157: H7 ATCC 43895) as Gram negative were grown in liquid Mueller Hinton Broth overnight in a shaker incubator. The concentrations of the microorganisms were adjusted to be equal to 0.5 McFarland standard $\left(1.5 \times 10^{+8} \mathrm{CFU} / \mathrm{ml}\right)$. The empty discs were loaded with $20 \mu \mathrm{l}$ of stock $200 \mathrm{mg} / \mathrm{ml} \quad C$. cornucopioides extracts and placed on petri plates for disk diffusion method. Gentamicin was used as the standard antibiotic. Then A. tumefaciens $\left(28^{\circ} \mathrm{C}\right)$ and other microorganisms $\left(35^{\circ} \mathrm{C}\right)$ were incubated overnight to examine the antimicrobial activity in the petri dishes. At the end of this period, the zones of inhibition around the discs were measured by means of a digital ruler.

\subsubsection{Cytotoxic effects on HepG2 cells}

HepG2 (human hepatocellular cancer) cells were used to investigate of cytotoxic effect of aqueous and methanol extracts of C. cornucopioides. Growth medium (RPMI with L-glutamine) was heated to $37^{\circ} \mathrm{C}$ and cells were added. Then, they were grown in a $5 \% \mathrm{CO}_{2}$ incubator (Sanyo, USA) at $37{ }^{\circ} \mathrm{C}$ with $95 \%$ humidity. One day after, the cells were washed with PBS and detached by trypsinization when $80-90 \%$ saturation was reached. Passaged cells were grown again at $37{ }^{\circ} \mathrm{C}$ in $5 \% \mathrm{CO}_{2}$ (Sanyo MCO 17AIC, USA) until confluency of $90 \%$. The cytotoxic effects of $C$. cornucopioides extracts were determined in accordance with the manufacturer's protocol with the XTT cell proliferation assay kit (Biological Industries, Israel). For this, $50 \mu \mathrm{l}$ of activated XTT (Cell Proliferation Assay Kit) was added to the cells which were preincubated with different concentration of $C$. cornucopioides extracts for 48 hours at $37^{\circ} \mathrm{C}, 5 \% \mathrm{CO}_{2}$. At the end of the $5 \mathrm{~h}$ XTT incubation, absorbance values at $450 \mathrm{~nm}$ was measured with a microplate reader (Multiskan $^{\text {TM }}$ GO, Thermo Scientific, USA) and $\mathrm{IC}_{50}$ values were calculated.

\subsection{Statistical Analyses}

All the assays were carried out at least in triplicate measurements. The results are expressed as mean values and standard error of mean (SEM). Antioxidant, antibacterial and cytotoxicity activities were analyzed using Student t-test and values with $\mathrm{P}<0.05$ were considered as statistically significant. $\mathrm{IC}_{50}$ and $\mathrm{EC}_{50}$ values were calculated with non-lineer regression analysis. For all statistical calculations Statistical Package for Social Sciences (SPSS ${ }^{\circledR}$, version 21.0) were utilized.

\section{Results}

Health and nutrition problems are getting increase due to world population which is irregularly growing. Nowadays, unconscious consumption of natural resources and economic difficulties obligates the use of natural resources and this increases the importance of macrofungi in diet. In addition to the nutritional properties, their biologically active substances have gained reputation in the pharmaceutical area.

In studies of antioxidant, antimicrobial and cytotoxic activities of macrofungi and other medical effects, important data have been obtained. In this study, antioxidant, antimicrobial and cytotoxic activities of Craterellus cornucopioides (L.) Pers. is researched.

Amount of bioactive compounds present in aqueous and methanolic extracts of $C$. cornucopioides are summarized in Table 1. Results demonstrated that water extracts of $C$. cornucopioides has very high amount of total phenolics $(37.71 \pm 1.42 \mu \mathrm{g} / \mathrm{mg})$ which is also in parallel with the main phenolics; gallic acid and p-coumaric acid determined with HPLC analysis. Similarly, total flavonoid contents $(2.13 \pm 0.06 \mu \mathrm{g} / \mathrm{mg})$ were also higher as compared with methanolic extracts $(1.83 \pm 0.02 \mu \mathrm{g} / \mathrm{mg})$. On the other hand, methanolic extracts have higher content of the $\beta$-carotene and lycopene. Additionally, the phenolic compounds such as gallic acid, catechin, epicatechin, epigallocatechin gallate, syringic acid, p-coumaric acid, rosmarinic acid, t-resveratrol and quercetin in $C$. cornucopioides extracts were quantitatively determined by HPLC but, the amount of other phenolic compounds, except p-coumaric acid and gallic acid was either under HPLC limit or had no in C. cornucopioides extracts.

Table 1: Antioxidant activity, reducing power and bioactive ingredients of $C$. cornucopioides extracts.

\begin{tabular}{|c|c|c|}
\hline $\begin{array}{l}\text { Bioactive } \\
\text { Ingredients }\end{array}$ & $\begin{array}{c}\text { C. cornucopioides } \\
\text { extract }\end{array}$ & Content \\
\hline \multirow{2}{*}{$\begin{array}{l}\text { DPPH scavenging } \\
\left(\mathrm{IC}_{50}: \mathrm{mg} / \mathrm{ml}\right)\end{array}$} & Water & $12.01 \pm 1.72$ \\
\hline & $\mathrm{MeOH}$ & $5.26 \pm 0.67$ \\
\hline \multirow{2}{*}{$\begin{array}{l}\text { Reducing power } \\
\left(\mathrm{EC}_{50}: \mathrm{mg} / \mathrm{ml}\right)\end{array}$} & Water & $4.54 \pm 0.61$ \\
\hline & $\mathrm{MeOH}$ & $6.52 \pm 1.53$ \\
\hline \multirow{2}{*}{$\begin{array}{l}\text { Phenolics } \\
(\mu \mathrm{g} / / \mathrm{mg})\end{array}$} & Water & $37.71 \pm 1.42$ \\
\hline & $\mathrm{MeOH}$ & $13.78 \pm 1.59$ \\
\hline \multirow{2}{*}{$\begin{array}{l}\text { B-carotene } \\
(\mu \mathrm{g} / \mathrm{mg})\end{array}$} & Water & $3.89 \pm 0.06$ \\
\hline & $\mathrm{MeOH}$ & $6.34 \pm 0.08$ \\
\hline \multirow{2}{*}{$\begin{array}{l}\text { Lycopene } \\
(\mu \mathrm{g} / \mathrm{mg})\end{array}$} & Water & $2.49 \pm 0.01$ \\
\hline & $\mathrm{MeOH}$ & $5.55 \pm 0.08$ \\
\hline \multirow{2}{*}{$\begin{array}{l}\text { Flavonoid } \\
(\mu \mathrm{g} / \mathrm{mg})\end{array}$} & Water & $2.13 \pm 0.06$ \\
\hline & $\mathrm{MeOH}$ & $1.83 \pm 0.02$ \\
\hline \multirow{2}{*}{$\begin{array}{l}\text { Gallic Acid } \\
(\mu \mathrm{g} / \mathrm{mg})\end{array}$} & Water & $0.55 \pm 0.02$ \\
\hline & $\mathrm{MeOH}$ & $0.29 \pm 0.02$ \\
\hline \multirow{2}{*}{$\begin{array}{l}\text { p-coumaric acid } \\
(\mu \mathrm{g} / \mathrm{mg})\end{array}$} & Water & $3.73 \pm 0.01$ \\
\hline & $\mathrm{MeOH}$ & $1.76 \pm 0.01$ \\
\hline
\end{tabular}

DPPH radical scavenging activities were measured with different concentrations of $C$. cornucopioides up to 10 $\mathrm{mg} / \mathrm{ml}$ of extracts and scavenging activities enhanced with elevated concentrations (Fig. 1). The best radical scavenging was obtained with the methanolic extracts of C. cornucopioides in $10 \mathrm{mg} / \mathrm{ml}$ concentration, as over than $75 \%$ DPPH reduction takes place. Aqueous extracts of the same mushrooms also possessed $40 \%$ inhibition at highest concentration tested. According to $\mathrm{IC}_{50}$ values, methanolic extracts of $C$. cornucopioides $\left(\mathrm{IC}_{50}: 5.26 \pm 0.67 \mathrm{mg} / \mathrm{ml}\right.$ ) are more efficient than its aqueous extracts $\left(\mathrm{IC}_{50}: 12.01 \pm 1.72\right.$ $\mathrm{mg} / \mathrm{ml})$. 


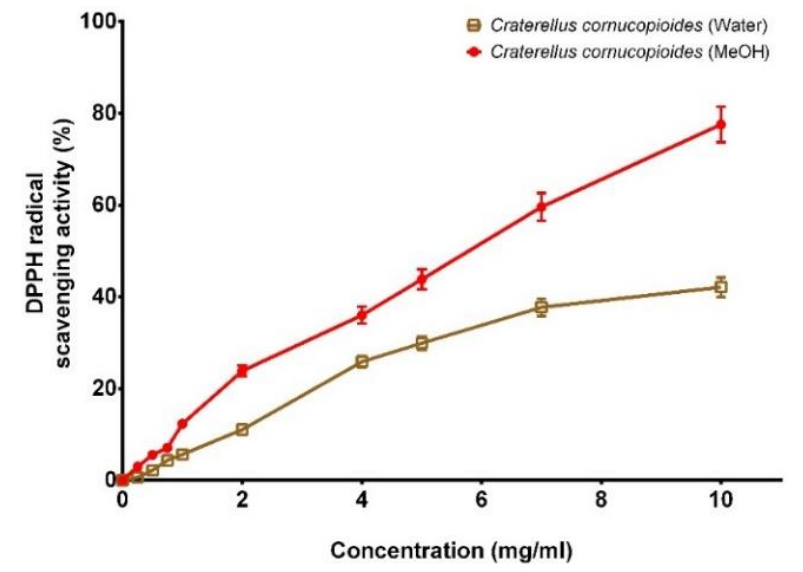

Figure 1: DPPH radical scavenging activities of aqueous and methanolic extracts of $C$. cornucopioides.

Reducing power of a pharmaceutical generally strongly correlates well with the antioxidant capacity. Therefore, $\mathrm{EC}_{50}$ values were determined to describe the extract concentration yielding an absorbance value of 0.500 . According to the results, aqueous extracts showed higher reducing activity than methanolic extracts in general view (Fig. 2). Aqueous extract of $C$. cornucopioides had the highest reducing activity with the lowest $\mathrm{EC}_{50}$ value $(4.54 \pm 0.61 \mathrm{mg} / \mathrm{ml})$.

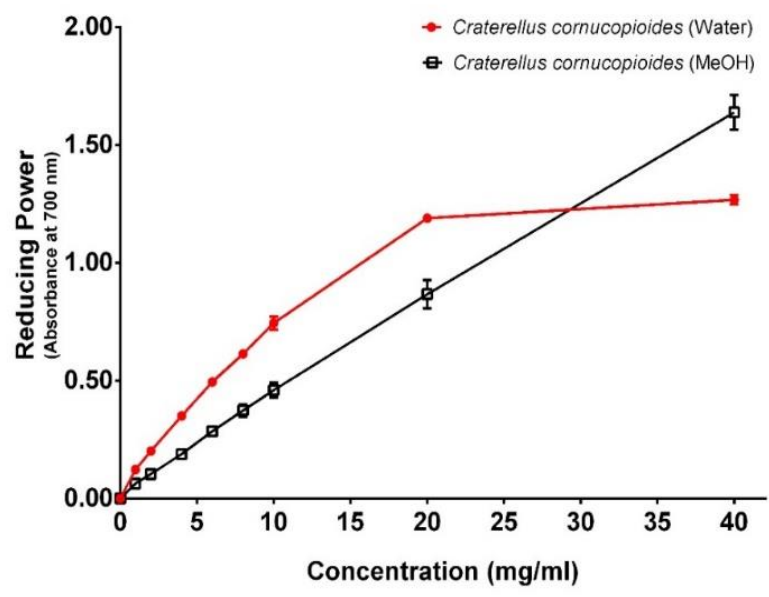

Figure 2: Reducing powers of aqueous and methanolic extracts from C. cornucopioides.

Cell growth inhibitory potentials of $C$. cornucopioides extracts on HepG2 cells were also inspected in this study, which was not reported previously. Results indicated that extracts have some degree of cytotoxicity over HepG2 cells and cytotoxic effects of the extracts increased with elevated concentrations (Fig. 3). Methanolic extracts of $C$. cornucopioides had the lowest $\mathrm{IC}_{50}$ values $(3.14 \pm 1.07$ $\mathrm{mg} / \mathrm{ml})$. Considering the water extracts, $\mathrm{IC}_{50}$ values of $18.41 \pm 1.10 \mathrm{mg} / \mathrm{ml}$ were obtained showing that methanolic extracts has higher cell growth inhibitory potential. As a result, $C$. cornucopioides might play a role in cancer and related researches in cytotoxic effect studies.

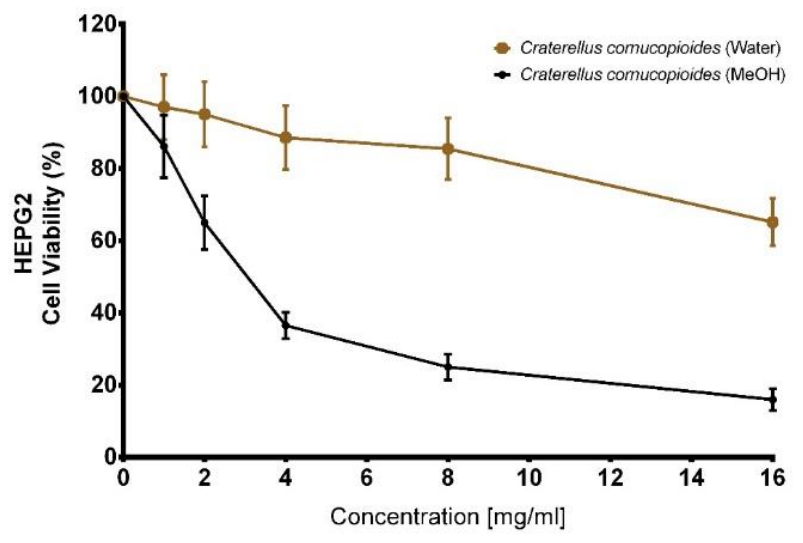

Figure 3: Cytotoxicity of aqueous and methanolic extracts from C. cornucopioides over HepG2 cells after 48 hours exposure time.

In antibacterial studies, it was revealed that extracts of $C$. cornucopioides have high antimicrobial potential. As it can be seen clearly in Table 2, C. cornucopioides exerted antibacterial activity on all tested microorganisms; $B$. subtilis, E. faecalis, B. licheniformis, A tumefaciens, E. coli and $S$. aureus. With its both water and methanolic extracts, $C$. cornucopioides inhibited microbial growth with inhibitory zone (IZ) values ranging 6-8 $\mathrm{mm}$ length.

Table 2: Antibacterial effects of $C$. cornucopioides on six different tested microorganisms.

\begin{tabular}{|c|c|c|c|}
\hline $\begin{array}{l}\text { Tested } \\
\text { Bacteria }\end{array}$ & Extract & $\begin{array}{l}\text { C. cornucopioides } \\
\text { IZ: } \mathbf{~ m m}\end{array}$ & $\begin{array}{l}\text { Gentamicin } \\
\text { IZ: cm }\end{array}$ \\
\hline \multirow{2}{*}{ E. coli } & Water & 6 & \multirow{2}{*}{2.3} \\
\hline & $\mathrm{MeOH}$ & 7 & \\
\hline \multirow[b]{2}{*}{ S. aureus } & Water & 6 & \multirow{2}{*}{2.4} \\
\hline & $\mathrm{MeOH}$ & 6 & \\
\hline \multirow{2}{*}{ B. subtilis } & Water & 6 & \multirow{2}{*}{2.5} \\
\hline & $\mathrm{MeOH}$ & 8 & \\
\hline \multirow{2}{*}{ B. licheniformis } & Water & 6 & \multirow{2}{*}{2.4} \\
\hline & $\mathrm{MeOH}$ & 7 & \\
\hline \multirow[b]{2}{*}{ A. tumefaciens } & Water & 6 & \multirow{2}{*}{2.7} \\
\hline & $\mathrm{MeOH}$ & 7 & \\
\hline \multirow{2}{*}{ E. faecalis } & Water & 6 & \multirow{2}{*}{2.5} \\
\hline & $\mathrm{MeOH}$ & 7 & \\
\hline
\end{tabular}

In conclusion, in the near feature mashrooms having nutritional and economical values will be more used in medicine, pharmacy and industrial area due to their high antioxidant, antimicrobial, and cytotoxic features. $C$. cornucopioides shows noticeable activities with its antioxidant, antibacterial and cell growth inhibitory potential together with high gallic acid and p-coumaric acid content. It might be utilized as a promising source of therapeutics since it might provide an appropriate source of antioxidant, antibacterial and cytotoxic natural compounds and also could be searched as potent antibacterial drugs against infectious diseases.

\section{Acknowledgments}

This research was supported by Karamanoğlu Mehmetbey University (10-YL-15). 


\section{References}

Alves MJ, Ferreira ICFR, Martins A, Pintado M (2012). Antimicrobial activity of wild mushroom extracts against clinical isolates resistant to different antibiotics. J Appl Microbiol 113(2):466-475.

Barros L, Ferreira MJ, Queiros B, Ferreira ICFR, Baptista P (2007). Total phenols, ascorbic acid, $\beta$-carotene and lycopene in Portuguese wild edible mushrooms and their antioxidant activities. Food Chem 103:413-419.

Chang ST, Buswell JA (1996). Mushroom nutriceuticals. World J Microb Biot 12: 473-476.

Chang ST, Wasser SP (2012). The role of culinary medicinal mushrooms on human welfare with a pyramid model for human health. Int J Med Mushrooms 14:95-134.

Cheung LM., Cheung PCK, Ooi VEC (2002). Antioxidant activity and total phenolics of edible mushroom extracts. Food Chem 81: 249-255

Gan CH, Nurul AB, Asmah R (2013). Antioxidant analysis of different types of edible mushrooms (Agaricus bisporous and Agaricus brasiliensis). Int Food Res J 20(3): 1095-1102.

Jagadish LK, Krishnan VV, Shenbhagaraman R, Kaviyarasan V (2009). Comparative study on the antioxidant, anticancer and antimicrobial property of Agaricus bisporus (J. E. Lange) Imbach before and after boiling. African J Biot 8(4): 654-661.

Karamac M, Amarowichz R, Weidner S, Abe S, Shahidi F (2002). Antioxidant activity of rye caryopses and embryos extracts. Czech J Food Sci 20: 209-214.

Kozarski M, Klaus A, Jakovljevic D, Todorevic N, Vunduk J, Petrovic P (2015). Antioxidants of edible mushrooms. Molecules 20: 19489-19525.

Manivannan E, Kothai R, Arul B, Rajaram S (2011). In-vitro antioxidant properties of Sterculia foetida Linn. Res J Pharm Biol Chem Sci 2:43-52.

Mattila P, Suonpaa K, Piironen V (2000). Functional properties of edible mushrooms. Nutrition 16(7-8):694-696.

Pal J, Ganguly S, Tahsin KS, Acharya K (2010). In vitro free radical scavenging activity of wild edible mushroom, Pleurotus squarrosulus (Mont.) Singer. Indian J Exp Biol 48:1210- 1218.

Pan HH, Yu XT, Li T, Wu HL, Jiao CW, Cai MH, Li XM, Xie YZ, Wang Y, Peng T (2013). Aqueous extract from a Chaga medicinal mushroom, Inonotus obliquus (higher Basidiomycetes), prevents herpes simplex virus entry through inhibition of viral-induced membrane fusion. Int J Med Mushrooms 15: 29-38.

Palacios I, Lozano M, Moro C, D’Arrigo M, Rostagno MA, Martinez JA, García-Lafuente A, Guillamón E, Villares A (2011). Antioxidant properties of phenolic compounds occurring in edible mushrooms. Food Chem 3: 674-678

Sadi G, Emsen B, Kaya A, Kocabaş A, Çınar Ş, Kartal Dİ (2015). Cytotoxicity of some edible mushrooms extracts overliver hepatocellular carcinoma cells in conjunction with their antioxidant and antibacterial properties. Pharmacogn Mag, 1:6-18

Smania EFA, Delle Monache F, Smania Jr A, Yunes RA, Cuneo RS (2003). Antifungal activity of sterols and triterpenes isolated from Ganoderma annulare. Fitoterapia 74:375-377.

Smania Jr A, Delle Monache F, Smania EFA, Cuneo RS (1999). Antibacterial activity of steroidal compounds isolated from Ganoderma applanatum (Pers.) Pat. (Aphyllophoromycetideae) fruit body. Int J Med Mushrooms 1:325-330.

Türkoğlu A, Duru ME, Mercan N, Kıvrak İ, Gezer K (2007). Antioxidant and antimicrobial activities of Laetiporus sulphureus (Bull.) Murril. Food Chem 101: 267-273.

Yen GC, Chen HY (1995). Antioxidant activity of various tea extracts in relation to their antimutagenicity. J of Agri Food Chem 43: 27-32.

Yıldız O, Can Z, Laghari AQ, Şahin H, Malkoç M (2015). Wild edible mushrooms as a natural source of phenolics and antioxidants. J Food Biochem 39:148-154

Taga MS, Miller EE, Pratt DE (1984) Chia seeds as a source of natural lipid antioxidants. J Am Oil Chem Soc 61(5):928-931.

Cite this article: Kol S, Bostancı A, Kocabaş A, Uzun Y, Sadi G (2018). Cell growth inhibitory potential of Craterellus cornucopioides (L.) Pers. together with antioxidant and antimicrobial properties. Anatolian Journal of Botany 2(2): 60-64. 